\title{
Worlding the south
}

Nineteenth-century literary culture and the southern settler colonies

\section{Edited by Sarah Comyn} Porscha Fermanis 


\section{WORLDING THE SOUTH}

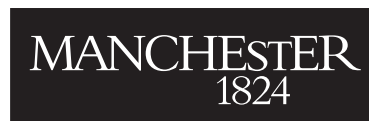

Manchester University Press 


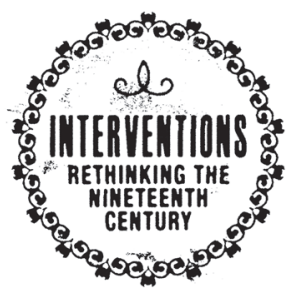

Series editors: Anna Barton, Andrew Smith

Editorial board: David Amigoni, Isobel Armstrong, Philip Holden, Jerome McGann, Joanne Wilkes, Julia M. Wright

Interventions: Rethinking the Nineteenth Century seeks to make a significant intervention into the critical narratives that dominate conventional and established understandings of nineteenthcentury literature. Informed by the latest developments in criticism and theory the series provides a focus for how texts from the long nineteenth century, and more recent adaptations of them, revitalise our knowledge of and engagement with the period. It explores the radical possibilities offered by new methods, unexplored contexts and neglected authors and texts to re-map the literary-cultural landscape of the period and rigorously re-imagine its geographical and historical parameters. The series includes monographs, edited collections, and scholarly sourcebooks.

Already published

Engine of modernity: The omnibus and urban culture in nineteenth-century Paris Masha Belenky

Spectral Dickens: The uncanny forms of novelistic characterization Alexander Bove

Pasts at play: Childhood encounters with history in British culture, 1750-1914

Rachel Bryant Davies and Barbara Gribling (eds)

The Case of the Initial Letter: Charles Dickens and the politics of the dual alphabet Gavin Edwards

Spain in the nineteenth century: New essays on experiences of culture and society

Andrew Ginger and Geraldine Lawless

Instead of modernity: The Western canon and the incorporation of the Hispanic (c.1850-75) Andrew Ginger

The Victorian aquarium: Literary discussions on nature, culture, and science Silvia Granata Marie Duval: Maverick Victorian cartoonist Simon Grennan, Roger Sabin and Julian Waite

Creating character: Theories of nature and nurture in Victorian sensation fiction Helena Ifill Margaret Harkness: Writing social engagement 1880-1921 Flore Janssen and Lisa C. Robertson (eds)

Richard Marsh, popular fiction and literary culture, 1890-1915: Re-reading the fin de siècle Victoria Margree, Daniel Orrells and Minna Vuohelainen (eds)

Charlotte Brontë: Legacies and afterlives Amber K. Regis and Deborah Wynne (eds)

The Great Exhibition, 1851: A sourcebook Jonathon Shears (ed.)

Interventions: Rethinking the nineteenth century Andrew Smith and Anna Barton (eds)

Counterfactual Romanticism Damian Walford Davies (ed.)

The poems of Elizabeth Siddal in context Anne Woolley 


\title{
Worlding the south
}

Nineteenth-century literary culture and the southern settler colonies

\author{
Edited by Sarah Comyn and \\ Porscha Fermanis
}

Manchester University Press 
While copyright in the volume as a whole is vested in Manchester University Press, copyright in individual chapters belongs to their respective authors.

This electronic version has been made freely available under a Creative Commons (CC-BY-NC-ND) licence, thanks to the support of the European Research Council, which permits non-commercial use, distribution and reproduction provided the editor(s), chapter author(s) and Manchester University Press are fully cited and no modifications or adaptations are made. Details of the licence can be viewed at https://creativecommons.org/licenses/by-nc-nd/4.0/.

Published by Manchester University Press Altrincham Street, Manchester M1 7JA

www.manchesteruniversitypress.co.uk

British Library Cataloguing-in-Publication Data A catalogue record for this book is available from the British Library

ISBN 9781526152886 hardback

First published 2021

The publisher has no responsibility for the persistence or accuracy of URLs for any external or third-party internet websites referred to in this book, and does not guarantee that any content on such websites is, or will remain, accurate or appropriate.

Cover image: Augustus Earle, 'Distant view of the Bay of Islands, New Zealand', watercolour, c.1827, National Library of Australia

Typeset

by Sunrise Setting Ltd, Brixham 